\title{
INHIBITION OF PLASMA KALLIKREIN WITH APROTININ IN PORCINE ENDOTOXIN SHOCK
}

\author{
Matthias Siebeck, MD, Edwin Fink, PhD, Joachim Weipert, MD, ${ }^{b}$ Marianne Jochum, PhD, ${ }^{b}$ Hans Fritz, PhD, ${ }^{b}$ \\ Michael Spannagl, MD, ${ }^{c}$ Peter Kroworsch," Kazuaki Shimamoto, MD, ${ }^{d}$ and Leonhard Schweiberer," MD
}

\begin{abstract}
Activation of the contact phase of coagulation has been implicated in the pathogenesis of septic shock. We wanted to determine if inhibition of plasma kallikrein can prevent arterial hypotension and liberation of kinins from kininogen, induced by an infusion of bacterial lipopolysaccharide (LPS) in anesthetized, ventilated 20-kg pigs. The LPS was given IV in a dose of $5 \mu \mathrm{g} / \mathrm{kg} / \mathrm{h}$ for 8 hours. The plasma kallikrein inhibitor aprotinin, $537 \mu \mathrm{mol}$, was given IV during 8 hours, resulting in plasma levels above $10 \mu \mathrm{mol} / \mathrm{L}$. Ten animals (SA) received LPS and aprotinin and ten randomized controls (SC) received LPS and saline. Kinin-containing kininogen was determined on the basis of the amount of kinin releasable in plasma samples by incubation with trypsin. Kininogen decreased to $58 \% \pm 4 \%$ of the baseline value without any difference between groups. This may indicate participation of other processes than degradation by plasma kallikrein in the decrease of kininogen. Arterial blood pressure was higher at 7 hours in the SA animals than in the SC group $(101 \% \pm 11 \%$ vs. $68 \% \pm 8 \%$; mean \pm SEM; $p=0.026)$. Fibrin monomer and $C 3 \mathrm{a}_{\text {desArg }}$ plasma levels were attenuated by aprotinin treatment. These findings underscore the important role of the contact system in LPS shock.
\end{abstract}

BACTERIAL LIPOPOLYSACCHARIDE (LPS) is regarded as one of the causative agents of gram-negative sepsis and has been demonstrated to activate the contact phase of the intrinsic blood coagulation cascade in vitro. ${ }^{1,2}$ Arterial hypotension is induced by LPS in many species of experimental animals. Both the contact and the complement systems have been found to be activated in patients with septic shock. ${ }^{3}$

Activation of the contact system of blood coagulation (Fig. 1) occurs as reciprocal activation of plasma kallikrein and Hageman factor (factor XII) in the presence of a negatively charged surface and high molecular weight kininogen (HMr kininogen) as cofactors. ${ }^{4}$ Activation leads to release of bradykinin from kininogen by plasma kallikrein, ${ }^{5}$ intrinsic blood coagulation, fibrinolysis, ${ }^{6}$ complement activation, ${ }^{7}$ and neutrophil stimulation. ${ }^{8}$ The potent hypotensive oligopeptide bradykinin has been implicated in the pathophysiology of shock. ${ }^{9} \mathrm{De}$ creased kininogen and prekallikrein concentrations ${ }^{10}$ and elevated kinin levels ${ }^{11}$ in plasma have been repeatedly described in experimental LPS shock and in patients with septic shock. Using a specific kinin receptor antag-

From the a Department of Surgery, the ${ }^{\mathrm{D}}$ Division of Clinical Chemistry and Clinical Biochemistry in the Department of Surgery, and the 'Department of Medicine, University of Munich, Klinikum Innenstadt, Munich, Federal Republic of Germany, and the " Second Department of Internal Medicine, Sapporo Medical College, Sapporo, Japan.

Address for reprints: Matthias Siebeck, MD, Department of Surgery, University of Munich, Nussbaumstrasse 20, D-8000 München 2, Germany. onist it was demonstrated that kinins mediate LPSinduced arterial hypotension in rats. ${ }^{12}$

According to these results generation of active plasma kallikrein by contact system activation and subsequent release of bradykinin could play an important role in the pathophysiology of LPS-induced shock. To test this hypothesis we investigated whether in vivo inhibition of plasma kallikrein with aprotinin, a plasma kallikrein inhibitor, ${ }^{13}$ would block or attenuate the effect of LPS on blood pressure and the concentration of uncleaved kininogen in pigs. Further questions concerned the effect of aprotinin on LPS-induced respiratory failure and on activation of the complement and coagulation systems.

\section{MATERIALS AND METHODS}

Miniature pigs (Medical Service $\mathrm{GmbH}$, Munich) with a body weight ranging from 18.0 to $22.0 \mathrm{~kg}$ were used in our study. All animal procedures were approved by the government of Oberbayern. The animals were fasted overnight but had free access to water. Sedation was achieved by intramuscular injection of azaperone, $3 \mathrm{mg} / \mathrm{kg}$, and metomidate, $3.75 \mathrm{mg} / \mathrm{kg}$. After induction of anesthesia with intravenous pentobarbital sodium, $24 \mathrm{mg} / \mathrm{kg}$, volume-cycled mechanical ventilation was instituted with a Servo Ventilator $900 \mathrm{C}$ (Siemens Elema AB, Sweden) at constant settings. Tidal volume was increased only if carbon dioxide partial pressure in arterial blood rose above $40 \mathrm{~mm} \mathrm{Hg}$ during the experiment. Metabolic acidosis was corrected with infusion of $1 \mathrm{~N} \mathrm{NaHCO}_{3}$ solution if base excess reached -2 $\mathrm{mEq} / \mathrm{L}$ in hourly arterial blood gas analyses. A $7 \mathrm{~F}$ thermistortipped Swan-Ganz catheter was placed in the internal jugular vein and passed to the pulmonary artery; three venous catheters for infusions and a short large-bore cannula for sampling blood 


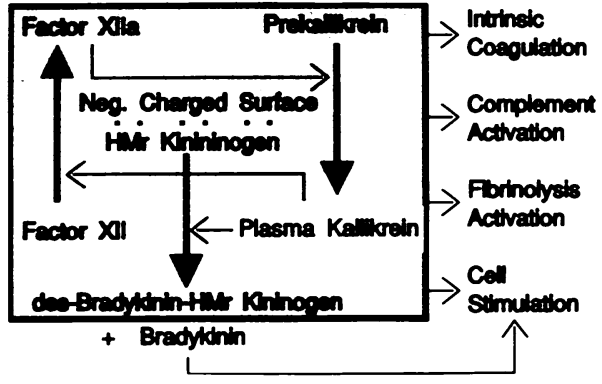

Figure 1. The contact system of blood coagulation. When the zymogens, Hageman factor (factor XII), and prekallikrein are bound to $\mathrm{HMr}$ kininogen and brought into contact with a negatively charged surface, they activate each other mutually. The active factor XII (factor XIIa) converts more prekallikrein into active plasma kallikrein, which in turn converts more factor XII into factor XIla and cleaves the peptide bradykinin from HMr kininogen. Plasma kallikrein and factor XIla initiate several other metabolic pathways such as the coagulation, complement, and fibrinolysis cascades. Plasma kallikrein stimulates granulocytes; bradykinin stimulates endothelial cells and induces hypotension. All of these events could be possibly blocked by an inhibitor of plasma kallikrein.

were placed in the external jugular vein. Piritramide, $15 \mathrm{mg}$, and pancuronium bromide, $4 \mathrm{mg}$, were given intravenously. Piritramide was continued at a rate of $0.5 \mathrm{mg} / \mathrm{kg} / \mathrm{h}$ and pancuronium bromide at a rate of $0.3 \mathrm{mg} / \mathrm{kg} / \mathrm{h}$. Additional pentobarbital sodium, $4 \mathrm{mg} / \mathrm{kg}$, was injected when necessary. Blood pressure was measured with a strain gauge connected to an aortic catheter placed via a femoral incision. A cystostomy tube was placed from a small midline incision, and urine was collected in hourly samples. During a 60 -minute resting period after the end of the surgical procedure $500 \mathrm{~mL}$ of Ringer's solution was infused.

Lipopolysaccharide shock was induced by a continuous infusion of bacterial lipopolysaccharide from Salmonella abortus $e^{e q u i}{ }^{14}$ (Sebak GmbH, Aidenbach, Germany). The LPS was dissolved in saline and given in a dose of $5 \mu \mathrm{g} / \mathrm{kg} / \mathrm{h}$ for 8 hours. Aprotinin $\left(\mathrm{M}_{\mathrm{r}}\right.$ 6512) was supplied by Bayer AG, Wuppertal (Batch No. 8078) as a white lyophilized powder with a specific activity of $7151 \mathrm{KIU} / \mathrm{mg}$ polypeptide. Aprotinin, $3.5 \mathrm{~g}(\triangleq 25$ million KIU $\triangleq 537 \mu \mathrm{mol}$ ), was freshly dissolved in saline and administered intravenously as a bolus of $750 \mathrm{mg}$ for 3 minutes before the start of LPS infusion followed by a continuous infusion of $2750 \mathrm{mg}$ for 8 hours. This dosage had been determined in eight pilot experiments.

After certain predetermined entry criteria had been fulfilled, baseline measurements were taken and the animals were randomly assigned to the study groups. Ten animals received LPS and aprotinin (SA) and ten controls received LPS and saline (SC). Animals were sacrificed after 8 hours of observation. Four nonseptic controls received saline and aprotinin in the aforementioned dose (NA); these animals were observed for 6 hours only. Five nonseptic controls received saline only (NN). Only the prekallikrein measurements were reported of this latter group. Blood samples were drawn at baseline and hourly thereafter, and processed to EDTA, or heparinized or citrated plasma, respectively, and kept at $-80^{\circ} \mathrm{C}$ until assayed.

Total kinin-containing kininogen was determined as follows: $20 \mu \mathrm{L}$ of heparinized plasma was mixed with $180 \mu \mathrm{L} 0.03 \mathrm{~mol} /$ $\mathrm{L} \mathrm{HCl}$ and incubated for 15 minutes at $37^{\circ} \mathrm{C}$. Thereafter, $10 \mu \mathrm{L}$ $0.5 \mathrm{~mol} / \mathrm{L} \mathrm{NaCl}, 30 \mu \mathrm{L} 0.3 \mathrm{~mol} / \mathrm{L}$ TRIS $/ \mathrm{HCl}, \mathrm{pH} 7.8$, and 10 $\mu \mathrm{L}$ of a trypsin solution (bovine trypsin, $2 \mathrm{mg} / \mathrm{mL}$ in $2.5 \mathrm{mmol} /$ $\mathrm{L} \mathrm{HCl}$ ) were added). After an incubation for 30 minutes at $37^{\circ} \mathrm{C}$ the solution was mixed with $1 \mathrm{~mL} 98 \%$ ethanol and heated for 10 minutes at $70^{\circ} \mathrm{C}$. After centrifugation at $12,000 \mathrm{~g}$ the supernatant was quantitatively transferred to a new tube and the ethanol was removed under vacuum in a SpeedVac concentrator. The dry residue was dissolved in radioimmunoassay buffer and the kinin concentration was determined by radioimmunoassay as described previously. ${ }^{15}$

Aprotinin concentration in citrated plasma samples was determined using an enzyme immunoassay. ${ }^{16}$ Plasma kallikrein was measured as the amount of latent prekallikrein in the sample that can be converted to the active enzyme by the addition of a mixture of ellagic acid, phospholipid, factor XII, and HMr kininogen (Kabi Vitrum, Mölndal, Sweden). The active plasma kallikrein was determined in a photometric assay using the chromogenic substrate $\mathrm{S} 2302$. The reaction is inhibited by aprotinin, therefore prekallikrein could not be determined in animals receiving aprotinin.

Plasma levels of $\mathrm{C} 3 \mathrm{a}_{\mathrm{des}}$ arg were determined with a newly developed radioimmunoassay similar to that described for human $\mathrm{C} 3 \mathrm{a}_{\text {desArg. }}{ }^{17}$ The $\mathrm{C} 3 \mathrm{a}_{\text {desArg }}$ was isolated from porcine blood ${ }^{18}$ and antiserum to $\mathrm{C} 3 \mathrm{a}_{\text {desArg }}$ was developed in rabbits.

\section{Buffers}

Buffer A: $0.015 \mathrm{~mol} / \mathrm{L} \mathrm{NaH}_{2} \mathrm{PO}_{4}, 0.15 \mathrm{~mol} / \mathrm{L} \mathrm{NaCl}, \mathrm{pH} 7.4$; buffer B: $0.015 \mathrm{~mol} / \mathrm{L} \quad \mathrm{NaH}_{2} \mathrm{PO}_{4}, 0.15 \mathrm{~mol} / \mathrm{L} \mathrm{NaCl}, 200$ $\mathrm{mg} / \mathrm{L}$ thimerosal, $1.0 \mathrm{~g} / \mathrm{L} \mathrm{NaN}_{3}, 42 \mathrm{~g} / \mathrm{L}$ bovine serum albumin, pH 7.4; buffer C: $0.05 \mathrm{~mol} / \mathrm{L} \mathrm{NaH}_{2} \mathrm{PO}_{4}, 0.1 \mathrm{~mol} / \mathrm{L} \mathrm{NaCl}, 200$ $\mathrm{mg} / \mathrm{L}$ thimerosal, $0.5 \mathrm{~g} / \mathrm{L} \mathrm{NaN}_{3}, 400 \mu \mathrm{L} / \mathrm{L}$ Tween $20, \mathrm{pH} 7.4$; buffer $\mathrm{D}: 8.0 \mathrm{~g} / \mathrm{L}$ ethodin in $0.05 \mathrm{~mol} / \mathrm{L} \mathrm{NaH}_{2} \mathrm{PO}_{4}, \mathrm{pH} 7.4$, freshly prepared immediately before use; buffer $\mathrm{E}: 0.015 \mathrm{~mol} /$ $\mathrm{L} \mathrm{NaH} \mathrm{PO}_{4}, 0.15 \mathrm{~mol} / \mathrm{L} \mathrm{NaCl}, 200 \mathrm{mg} / \mathrm{L}$ thimerosal, $60 \mathrm{~g} / \mathrm{L}$ polyethylene glycol 6000 .

\section{Radioiodination}

The C3 $\mathrm{a}_{\text {desArg }}$ was labeled with iodine-125 by the chloramine T method. ${ }^{19}$ Then $2.5 \mu \mathrm{g} \mathrm{C} \mathrm{a}_{\text {desArg }}, 0.33 \mathrm{mCi}(12.3 \mathrm{MBq}) \mathrm{Na}^{125} \mathrm{I}$, and $30 \mu \mathrm{g}$ chloramine $\mathrm{T}$ were incubated for $5-10$ seconds in buffer A (total volume $25 \mu \mathrm{L}$ ), and $60 \mu \mathrm{g}$ sodium disulfite dissolved in $60 \mu \mathrm{L}$ buffer $\mathrm{A}$ was added. The iodinated $\mathrm{C} 3 \mathrm{a}_{\text {desArg }}$ was purified by gel filtration of the mixture through a PD-10 column (Pharmacia). The column was eluted with buffer $A$. The pool of labeled $\mathrm{C} 3 \mathrm{a}_{\text {desArg }}$ was diluted with buffer $\mathrm{C}$ to 500,000 counts $\cdot \mathrm{min}^{-1} \cdot \mathrm{mL}^{-1}$, and $140 \mathrm{mg} / \mathrm{L}$ of rabbit immunoglobulin $\mathrm{G}$ was added.

\section{Sample Preparation}

Protein precipitation with 6,9-diamino-2 ethoxyacridine lactate (ethodin, Sigma Chemie, Deisenhofen) ${ }^{20}$ was employed to remove $\mathrm{C} 3$. One hundred microliters of EDTA-plasma was mixed with $100 \mu \mathrm{L}$ buffer D in Eppendorf tubes. After 20 minutes at room temperature the samples were centrifuged for 10 minutes at $10,000 \mathrm{~g}$. Dilutions of the supernatant with buffer $\mathrm{C}$ were analyzed in the radioimmunoassay.

\section{Radioimmunoassay Procedure}

The incubation mixtures consisting of $50 \mu \mathrm{L}$ of standard (1.0-500 $\mu \mathrm{g} / \mathrm{L})$ or sample in buffer $\mathrm{C}, 50 \mu \mathrm{L}$ iodinated $\mathrm{C} 3 \mathrm{a}_{\text {desArg }}$ in buffer $\mathrm{C}, 50 \mu \mathrm{L}$ buffer $\mathrm{C}$, and $50 \mu \mathrm{L}$ dilution of antiserum in buffer B were set up in 0.6-mL RIA tubes (Sarstedt, Nürmbrecht). After 12-18 hours' incubation at room temperature, 50 $\mu \mathrm{L}$ of a dilution of the precipitating antiserum (donkey antiserum to rabbit IgG, IDS, Washington, United Kingdom) in buffer $\mathrm{B}$ and $250 \mu \mathrm{L}$ buffer $\mathrm{E}$ was added. The tubes were centrifuged immediately for 20 minutes at $3500 \mathrm{~g}$. The radioactivity of the precipitates was measured in a gamma counter (Hydragamma 16; Zinsser, Frankfurt), and the results were evaluated on line by the RIALOG II program (Zinsser, Frankfurt).

Fibrin monomer was detected in plasma by a monoclonal 
antibody-based specific enzyme immunoassay; the capturing antibody used detects the $\mathrm{N}$-terminal $\alpha$-chain of porcine fibrin. The second antibody detected porcine fibrinogen. Thrombin digestion of known amounts of fibrinogen in pig plasma was used for standard preparation. The clottable fibrinogen in citrated plasma samples was measured using a functional turbidimetric test with batroxobin (Boehringer Mannheim, Germany). Total protein in plasma was measured with the Biuret reaction.

White blood cell counts were performed on a Contraves Hemocytometer. Alveolar-arterial oxygen gradient $\left(\mathrm{PAO}_{2}-\mathrm{PaO}_{2}\right)$ was calculated from arterial blood gas analyses made on a Corning Model 168 Blood Gas Analyzer and a Radiometer OSM2 Hemoximeter. Dynamic total compliance was calculated from data generated by the ventilator. Cardiac output was determined by the thermodilution method, and pulmonary vascular resistance (PVR) and systemic vascular resistance (SVR) were calculated. Creatinine was determined in plasma and urine using the picric acid method, and plasma clearance was calculated at 60-minute intervals.

After checking data for normality of distribution the twotailed Student's $t$ test was performed to compare the results of the two septic groups. Data were expressed as a percentage of the baseline value unless indicated as raw data. Mean values, standard error of the mean (SEM), and exact $p$ values were reported; no correction for multiple testing was made; $p$ values less than 0.05 were considered significant. The Wilcoxon signed-rank test was used for paired data. Survival was determined from the start of the LPS infusion to death; data were compared with the Mantel-Haenszel test.

\section{RESULTS}

\section{Circulation}

Mean arterial blood pressure (MAP) followed a biphasic time course during LPS infusion, was not different between groups at baseline, but was higher at 7 hours in the SA group than in the SC group $(101 \% \pm 11 \%$ vs. $68 \% \pm 8 \% ; p=0.026$; Fig. 2). Systemic vascular resistance (SVR) followed a time course similar to that of MAP, was marginally different between groups at base-

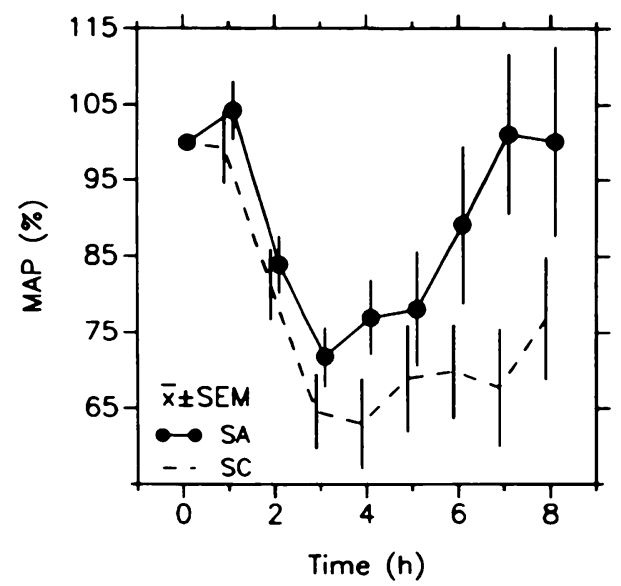

Figure 2. Mean arterial blood pressure (MAP) during LPS shock. Means \pm SEM (vertical bars) in percentage of the baseline value are given. Ten septic control animals (SC) received LPS, $5 \mu \mathrm{g} / \mathrm{kg} / \mathrm{h}$ for 8 hours and $0.9 \% \mathrm{NaCl}$ for 8 hours. Ten septic aprotinin-treated animals (SA) received LPS in the aforementioned dose, and aprotinin, $3.5 \mathrm{~g}$, for 8 hours. Pressure was higher in the SA group than in the SC group at 7 hours $(p=0.026)$.
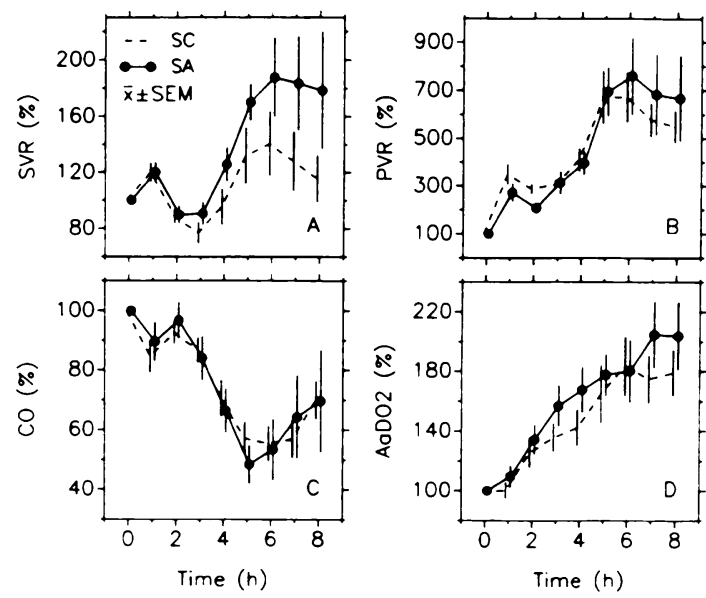

Figure 3. Systemic vascular resistance (SVR), pulmonary vascular resistance (PVR), cardiac output (CO), and alveolar-arterial oxygen gradient $\left(A-\mathrm{aDO}_{2}\right)$ during LPS shock. (A) The SVR was not significantly higher in the SA group than in the SC group. (B) The PVR was lower in the SA group than in the SC group at 2 hours $(p=0.04)$. (C) The CO was identical in the two groups. (D) The Alveolar-arterial oxygen gradient was identical in the two groups.

line $(p=0.06)$, and was not significantly higher in the SA group than in the SC group during LPS infusion (Fig. 3A). Cardiac output (CO) was not different between groups either at baseline or during the LPS infusion (Fig. $3 \mathrm{C})$.

\section{Lung}

Compliance dropped to $55 \%$ of the baseline; the alveolar-arterial oxygen gradient rose to $191 \%$ of the baseline value (Fig. 3D). No significant group differences developed for either of these variables during LPS infusion. Pulmonary vascular resistance followed a multiphasic time course with a peak at 30 minutes, a decline, and a secondary rise from 2 hours to 6 hours. At 2 hours, PVR was lower in the SA group $(207 \% \pm 23 \%)$ compared with the SC group $(287 \% \pm 21 \% ; p=0.04$; Fig. $3 \mathrm{~B})$. The results were similar for PAP $(p=0.004)$. Survival was $65 \%$ during 8 hours of LPS infusion; the groups were not significantly different ( $70 \%$ in the SC group, $60 \%$ in the SA group).

\section{Blood}

Kininogen concentration was not different between groups either at baseline or during LPS infusion and decreased to $58 \pm 4 \%$ of the baseline value (Fig. 4). Total protein concentration in plasma was not different between groups either at baseline or during LPS infusion and decreased to $69 \% \pm 2 \%$ of the baseline value (Fig. $5 \mathrm{~A})$. At 8 hours, the relative deviation from the baseline value was larger for kininogen than for total protein ( $p$ $=0.01$ ). Fibrin monomer was near the detection limit of the assay at baseline. During LPS infusion, fibrin monomer was considerably lower in the SA animals $(59 \% \pm$ $12 \mu \mathrm{g} / \mathrm{mL})$ than in the SC pigs $(152 \% \pm 27 \mu \mathrm{g} / \mathrm{mL} ; p=$ 0.013 at 8 hours; Fig. 5B). Fibrinogen decreased to $35 \%$ 


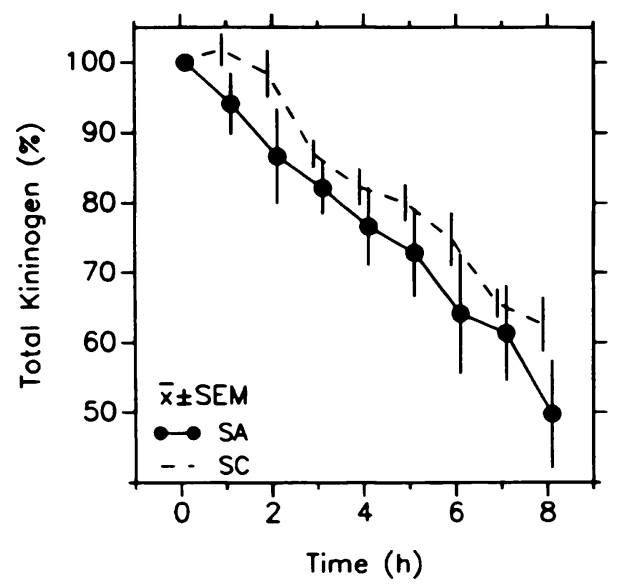

Figure 4. Total kininogen during LPS shock. Ten septic control animals (SC) received LPS, $5 \mu \mathrm{g} / \mathrm{kg} / \mathrm{h}$ for 8 hours and $0.9 \% \mathrm{NaCl}$ for 8 hours. Ten septic aprotinin-treated animals (SA) received LPS in the aforementioned dose, and aprotinin, $3.5 \mathrm{~g}$ for 8 hours. Groups were not significantly different. The assay detects only kinin-containing kininogen but not des-bradykinin-HMr kininogen.
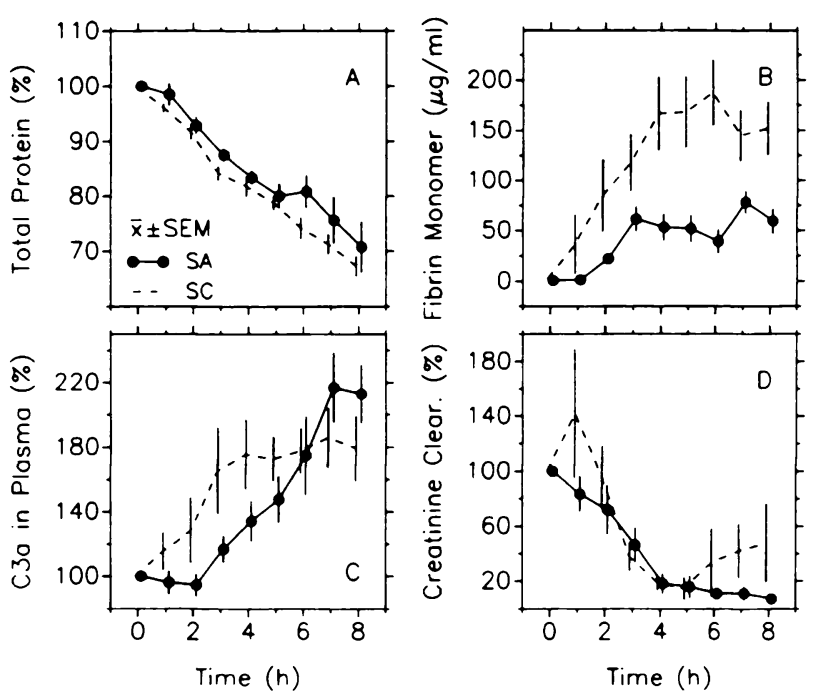

Figure 5. Total protein, fibrin monomer, $\mathrm{C} 3 \mathrm{a}_{\text {desarg }}$ in plasma, and creatinine clearance during LPS shock. Ten septic control animals (SC) received LPS, $5 \mu \mathrm{g} / \mathrm{kg} / \mathrm{h}$ for 8 hours and $0.9 \% \mathrm{NaCl}$ for 8 hours. Ten septic aprotinin-treated animals (SA) received LPS in the aforementioned dose, and aprotinin, $3.5 \mathrm{~g}$ for 8 hours. (A) Total protein was identical in the two groups. (B) Fibrin monomer concentration was substantially lower at 8 hours in the SA group than in the SC group $(p=0.013)$. (C) Complement fragment $\mathrm{C} 3 \mathrm{a}_{\text {desarg }}$ was slightly lower in the SA pigs than in the SC animals during the first 5 hours. (D) Creatinine clearance was nonsignificantly lower in the SA group than in the SC group.

at 8 hours. Fibrinogen was slightly higher at 6 hours in the SA group than in the SC group $(52 \% \pm 8 \%$ vs. $35 \%$ $\pm 5 \%$; NS). The C3a desarg level rose during LPS infusion to $195 \% \pm 14 \%$ of the baseline value at 8 hours. During the first 5 hours $\mathrm{C} 3 \mathrm{a}_{\text {desArg }}$ was slightly (NS) lower in the $\mathrm{SA}$ pigs than in the $\mathrm{SC}$ group (Fig. 5C). White blood cell count dropped to $20 \%$, without differences between the septic groups. Diuresis and creatinine clearance (Fig. 5D) were nonsignificantly lower in the SA group than in the $\mathrm{SC}$ group at 8 hours. Aprotinin concentration rose from $468 \pm 56 \mathrm{KIU} / \mathrm{mL}$ at 1 hour to $623 \pm 222 \mathrm{KIU} / \mathrm{mL}$ at 8 hours $(10 \pm 1.2$ to $13.6 \pm 4.8 \mu \mathrm{mol} / \mathrm{L})$ in the SA animals and from $423 \pm 61 \mathrm{KIU} / \mathrm{mL}$ at 1 hour to a maximum of $525 \pm 85$ at 5 hours in the NA group. Prekallikrein concentration decreased within 8 hours to $53 \% \pm 5 \%$ of the baseline value in the SC group and to $94 \% \pm 5 \%$ in nonseptic controls (NN; Fig. 6).

In the nonseptic aprotinin-treated animals (NA), total protein was completely stable. Minor deviations from normal were found for $\mathrm{PAO}_{2}-\mathrm{PaO}_{2}, \mathrm{PVR}, \mathrm{CO}, \mathrm{SVR}$, blood pressure, fibrinogen, and creatinine clearance. Plasma levels of $\mathrm{C} 3 \mathrm{a}_{\text {desArg }}$, prekallikrein, and kininogen were not determined in this group.

\section{DISCUSSION}

According to our primary hypothesis, activation of the contact system is important in the pathophysiology of LPS-induced shock and this activation induces the release of bradykinin from kininogen by activated plasma kallikrein. If this is the case, the administration of a plasma kallikrein inhibitor should reverse arterial hypotension and reduce LPS-induced kininogen breakdown. In fact, we found a significant reduction of LPSinduced hypotension. Since cardiac output had an identical time course whether or not aprotinin was given this difference in arterial blood pressure can be entirely attributed to a similar difference in the systemic vascular resistance.

To model the clinical situation of patients with gramnegative sepsis, we gave a continuous infusion of LPS in a dose of $5 \mu \mathrm{g} / \mathrm{kg} / \mathrm{h}$ for 8 hours. Most shock studies in rodents use 100 to 1000 -fold higher LPS doses. Injection of LPS from $E$. coli has been investigated in humans. However, septic shock and death are not acceptable risks for volunteers, and therefore much smaller doses $(4 \mathrm{ng} /$ $\mathrm{kg}$ ) have been used. ${ }^{21}$ Patients with gram-negative sepsis had endotoxin levels of between 6 and more than 100

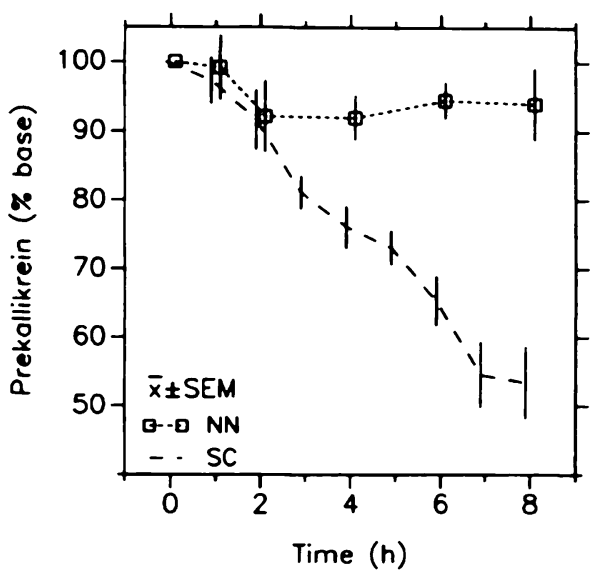

Figure 6. Prekallikrein in plasma with and without LPS shock. Ten septic control animals (SC) received LPS, $5 \mu \mathrm{g} / \mathrm{kg} / \mathrm{h}$ for 8 hours. Five nonseptic control animals (NN) received $0.9 \% \mathrm{NaCl}$ only. Prekallikrein levels decreased in the SC group but not in the NN group. Prekallikrein could not be measured in aprotinin-treated animals because a functional assay was used that is based on activation of prekallikrein to active plasma kallikrein, and measurement of the activity of plasma kallikrein thus released. Aprotinin, being a plasma kallikrein inhibitor, inhibits this reaction. 
$\mathrm{ng} / \mathrm{L}$ in blood. ${ }^{22}$ Pigs with endotoxin infusion in experiments similar to ours had endotoxin levels of approximately $4 \mathrm{ng} / \mathrm{mL} .^{23} \mathrm{We}$ did not select mortality as a primary study criterion because a longer observation period and a higher case number would have been necessary to detect an effect of aprotinin on survival. Small animals are better suited for this type of study, and other study conditions, e.g., a smaller dose of lipopolysaccharide, might have shown some improvement in mortality.

To assess cleavage of kininogen we used a method that determined the plasma concentration of kininogen by measuring the amount of kinin that can be released from a plasma sample by digestion with trypsin. In contrast to methods that employ antibodies directed against either high molecular weight kininogen ( $\mathrm{HMrK}$ ) or low molecular weight kininogen (LMrK), this method recognizes both $\mathrm{HMrK}$ and LMrK but only those kininogen molecules that still contain the kinin sequence. Using this method we found no difference of kininogen levels between the two septic groups. This finding suggests that activation of plasma kallikrein was not the only event responsible for the observed decrease in kininogen, which exceeded the decrease in total protein concentration significantly but only by $11 \%$. Processes other than proteolysis, e.g., the LPS-induced vascular leak syndrome or blood sampling, contribute to the decrease of plasma protein concentration in our experiments, and proteases other than plasma kallikrein may have contributed to the degradation of kininogen, ${ }^{24}$ e.g., polymorphonuclear elastase. ${ }^{25}$

It may be argued that our model of LPS shock failed to induce contact phase activation. Because of the principle of the plasma kallikrein assay used (determination of the kallikrein activity after in vitro activation of prekallikrein in the sample), it is not possible to determine kallikrein activity in the presence of high amounts of aprotinin. However, plasma kallikrein was activated in the LPS-treated animals as assessed in the absence of aprotinin by a substantial decrease in prekallikrein levels. Similarly, we have found in a previous study a decrease in the plasma activity of inhibitors of plasma kallikrein, $\mathrm{C} 1$ esterase inhibitor, and $\alpha_{2}$-macroglobulin. ${ }^{26}$

Aprotinin is a relatively weak plasma kallikrein inhibitor. However, the aprotinin plasma levels in our experiments exceeded $468 \mathrm{KIU} / \mathrm{mL}(10 \mu \mathrm{mol} / \mathrm{L})$ and should therefore have blocked relevant amounts of plasma kallikrein in the circulation. ${ }^{27,28}$ This notion is supported by a previous study in which high amounts of plasma kallikrein, rapidly generated in an in vivo model of dextran sulfate-induced activation of the contact phase of coagulation, were completely blocked at an aprotinin concentration of $400 \mathrm{KIU} / \mathrm{mL}{ }^{29}$

Since the extent of kininogen cleavage was not influenced by administration of aprotinin, the question arises why aprotinin then attenuated arterial hypotension. Aprotinin has been found to prevent the release of arachidonic acid from the membrane phospholipid pool ${ }^{30}$ and may thus inhibit the formation of prostanoids. Therefore it may even have an effect on blood pressure not related to kinins.

Contact system activation leads to activation of the coagulation, fibrinolysis, and complement pathways. C3 $\mathrm{a}_{\text {desArg }}$, a stable and biologically inert split product of $\mathrm{C} 3 \mathrm{a}$, showed a trend toward lower levels in aprotinintreated animals compared with controls during the first 5 hours of the LPS infusion, possibly indicating reduced complement activation. The formation of fibrin monomer was substantially reduced by aprotinin, and fibrinogen concentrations were higher during the last 3 hours in the SA animals than in the SC pigs, each finding indicating reduced activation of coagulation. Both the complement and the coagulation effects may have been produced by contact system inhibition, which would underline that plasma kallikrein activation had taken place in our experiment and was subject to inhibition by aprotinin.

It is important to note that aprotinin had no effect on leukocytopenia and respiratory dysfunction, both of which are very constant features of porcine LPS shock. An adverse side effect of high levels of aprotinin in septic shock may be impairment of renal function. Aprotinin given alone had no detrimental side effects, not even on renal function.

In summary, LPS-induced arterial hypotension, fibrin monomer formation, and $\mathrm{C} 3 \mathrm{a}_{\text {desArg }}$ release were attenuated by aprotinin at plasma levels around $10 \mu \mathrm{mol} / \mathrm{L}$, indicating the involvement of the contact system in the pathophysiology of LPS shock. Aprotinin had no effect on the kininogen decrease. We suggest that, in addition to plasma kallikrein, other processes contributed to kininogen turnover.

\section{Acknowledgments}

The study was carried out with the technical assistance of A. Braune, J. Kohl, C. Keser, G. Godec, and A. Oettl. This study was supported by a grant from the Bundesministerium des Inneren. Aprotinin was a generous gift of Dr. F. Schumann, Bayer AG, Wuppertal. C3 $\mathrm{a}_{\text {desArg }}$ isolated from porcine blood and antiserum to $\mathrm{C} 3 \mathrm{a}_{\text {desarg }}$ developed in rabbits was kindly provided by the late Prof. Damerau, Max-Planck-Institut für experimentelle Medizin, Göttingen. Dr. J. Weipert was the recipient of a fellowship from the Deutsche Forschungsgemeinschaft.

\section{REFERENCES}

1. Morrison DC, Cochrane CG: Direct evidence for Hageman factor (factor XII) activation by bacterial lipopolysaccharides (endotoxins). J Exp Med 140:797, 1974

2. Kalter ES, van Dijk WC, Timmerman A, et al: Activation of purified human plasma prekallikrein triggered by cell wall fractions of Escherichia coli and Staphylococcus aureus. J Infect Dis 148:682, 1983

3. Kalter ES, Daha MR, ten Cate JW, et al: Activation and inhibition of Hageman factor-dependent pathways and the complement system in uncomplicated bacteremia or bacterial shock. $J$ Infect Dis 151:1019, 1985

4. Cochrane CG, Griffin JH: The biochemistry and pathophysiology of the contact system of plasma. Adv Immunol 33:241, 1982 
5. Kaplan AP: Hageman factor-dependent pathways: Mechanism of initiation and bradykinin formation. Fed Proc 42:3123, 1983

6. Colman RW: Activation of plasminogen by human plasma kallikrein. Biochem Biophys Res Commun 35:273, 1969

7. Ghebrehiwet B, Randazzo BP, Dunn JT, et al: Mechanisms of activation of the classical pathway of complement by Hageman factor fragment. $J$ Clin Invest 71:1450, 1983

8. Wachtfogel YT, Kucich U, James HL, et al: Human plasma kallikrein releases neutrophil elastase during blood coagulation. $J$ Clin Invest 72:1672, 1983

9. Rocha é Silva M, Beraldo WT, Rosenfeld G: Bradykinin, a hypotensive and smooth muscle stimulating factor released from plasma globulin by snake venoms and by trypsin. Am $J$ Physiol 156:261, 1949

10. Aasen AO, Smith Erichsen N, Gallimore MJ, et al: Studies on components of the plasma kallikrein-kinin system in plasma samples from normal individuals and patients with septic shock. Adv Shock Res 4:1, 1980

11. O'Donnell TF, Clowes GHA, Talamo RC, et al: Kinin activation in the blood of patients with sepsis. Surg Gynecol Obstet 143:539, 1975

12. Weipert J, Hoffmann $\mathrm{H}$, Siebeck $M$, et al: Attenuation of arterial blood pressure fall in endotoxin shock in the rat using the competitive bradykinin antagonist Lys-Lys- $\left[\mathrm{Hyp}^{2}, \mathrm{Thi}^{5,8}{ }_{\mathrm{D}} \mathrm{Phe}^{7}\right]$ -BK (B4148). Br J Pharmacol 94:282, 1988

13. Fritz H, Wunderer G: Biochemistry and applications of aprotinin, the kallikrein inhibitor from bovine organs. Drug Res 33:479, 1983

14. Galanos C, Lüderitz O, Westphal O: Preparation and properties of a standardized lipopolysaccharide from Salmonella abortus equi. Zentralbl Bakteriol Orig A 243:226, 1979

15. Fink E, Schill WB, Fiedler F, et al: Tissue kallikrein of human seminal plasma is secreted by the prostate gland. Biol Chem Hoppe Seyler 366:917, 1985

16. Müller-Esterl W: Enzyme-linked immunosorbent assay for aprotinin. In Bergmeyer IU (ed): Methods of Enzymatic Analysis, Vol. XII. Weinheim, VCH Verlagsgesellschaft, 1986, pp 246-256

17. Hugli TE, Chenoweth D: Biologically active peptides of complement: Techniques and significance of $\mathrm{C} 3 \mathrm{a}$ and $\mathrm{C} 5 \mathrm{a}$ measurements. In Nakamura R, Dito S, Tucker E (eds): Immunoassays: Clinical Laboratory Techniques for the 1980s. New York, Alan R. Liss Inc., 1980, pp 443-460

18. Zimmermann B, Damerau B, Vogt W: Purification and partial amino acid sequence of classical anaphylatoxin from pig serum: Identification with Des-Arg-C5a. Hoppe-Seylers Z Physiol Chem $361: 915,1980$

19. Greenwood FC, Hunter WL, Glover JJ: The preparation of ${ }^{131} \mathrm{I}$ labelled growth hormone of high specific activity. Biochem $J$ 89:114, 1963

20. Steinbuch M, Niewiarowski S: Rivanol in the preparation of plasminogen (Profibrinolysin). Nature 186:87, 1960

21. Suffredini AF, Fromm RE, Parker MM, et al: The cardiovascular response of normal humans to the administration of endotoxin. $N$ Engl J Med 321:280, 1989

22. van Deventer SJ, Buller HR, ten Cate JW, et al: Endotoxaemia: An early predictor of septicaemia in febrile patients. Lancet 1(8586):605, 1988

23. Borg T, Alvfors A, Gerdin B, et al: A porcine model of early adult respiratory distress syndrome induced by endotoxinaemia. Acta Anaesthesiol Scand 29:814, 1985

24. McConn R, Wassermann F, Haberland G: The kallikrein-kinin system in the acutely ill: (A) Changes in plasma kininogen in acutely-ill patients. (B) The efficacy of pulmonary clearance of bradykinin. Adv Exp Med Biol 156:1019, 1983

25. McGuire WW, Spragg RG, Cohen AB, et al: Studies on the pathogenesis of the adult respiratory distress syndrome. $J$ Clin Invest 69:543, 1982

26. Siebeck M, Philapitsch A, Wiesinger $\mathrm{H}$, et al: C1-Esterase inhibitor in early septicemia. Prog Clin Biol Res 236A:141, 1987

27. Philipp E: Calculations and hypothetical considerations on the inhibition of plasmin and plasma kallikrein by trasylol. In Davidson JF, Rowan RM, Samama MM, Desnoyers PC (eds): Progress in Chemical Fibrinolysis and Thrombolysis, Vol 3. New York, Raven Press, 1978, pp 291-295

28. Fritz $\mathrm{H}$ : Inhibition of plasmin and plasma kallikrein by the basic trypsin-kallikrein inhibitor from bovine organs (Trasylol) and similar protease inhibitors: Theoretical considerations. In Davidson JF, Rowan RM, Samama MM, Desnoyers PC (eds): Progress in Chemical Fibrinolysis and Thrombolysis, Volume 3. New York, Raven Press, 1978, pp 285-290

29. Hoffmann $\mathrm{H}$, Siebeck $M$, Thetter $\mathrm{O}$, et al: Aprotinin concentrations effective for the inhibition of tissue kallikrein and plasma kallikrein in vitro and in vivo. Adv Exp Med Biol 247B:35, 1989

30. Seeger $\mathbf{W}$, Wolf $H$, Graubert $E$, et al: Influence of aprotinin and gabexate mesilate on arachidonic acid release by the $\mathrm{Ca}$-ionophore A 23187 in the lung. Adv Exp Med Biol 156:553, 1983 